\title{
MORPHOLOGICAL CHARACTERISTICS OF THE HERMANN'S TORTOISE (TESTUDO HERMANNI GMELIN, 1789) IN THE SOUTH-EASTERN PART OF KOSOVO AND METOHIJA
}

\author{
Nenad Labus ${ }^{1 *}$, Aleksandra Savić ${ }^{1}$, Nebojša Živić ${ }^{1}$, Tatjana Babović-Jakšić ${ }^{1}$ \\ ${ }^{1}$ Faculty of Natural Sciences and Mathematics, University of Priština, Kosovska Mitrovica, Serbia.
}

\section{ABSTRACT}

In this paper we present the results of the analysis of morphological characteristics of the Hermann's tortoise from three localities in southeastern part of Kosovo and Metohija. 75 adult Hermann's tortoises (33 males and 42 females) have been analyzed. Morphometric analisys has been done on 7 traits. We considered the plastron black pigmentation patterns and frequencies for each pigmentation states were calculated. Females were larger than males for all morphometric traits.
Based on the most important dimensions of carapace and plastron length and width, the Hermann's tortoises from the south-eastern part of Kosovo and Metohija are the most similar to the individuals of the population from the southern part of the Balkan Peninsula (the southern part of Serbia and the northern part of Greece). In relation to the populations from central and eastern Serbia, individuals from our studed area have higher values.

Key words: morphometry, Hermann's tortoise, Kosovo and Metohija.

\section{INTRODUCTION}

Hermann's tortoise (Testudo hermanni Gmelin, 1789) is distributed over the northern Mediterranean region. It is distributed over most of the Balkan Peninsula while in the western Mediterranean (continental Spain, France and Italy, Balearic Islands, Corsica, Sardinia and Sicily) has an isolated distribution. Although it is most prevalent in areas with a Mediterranean climate, it can be found in inland regions of the Balkan Peninsula under the influence of continental climate (Bour, 1997), (Cheylan, 2001), (Fritz et al., 2006), (Ljubisavljević et al., 2014).

The Hermann's tortoise is widely distributed in Serbia, where it inhabits hilly areas and lower mountains (below $1200 \mathrm{~m}$ ) south of the Sava and Danube rivers (Ljubisavljević et al., 2014), (Tomović et al., 2014).

It is generally accepted that two subspecies have been recognized within species Testudo hermanni (Fritz et al., 2006), (Bertolero et al., 2011), nominotypic Testudo hermanni hermanni and Testudo hermanni boettgeri. T. $h$. hermanni occupies the patchy western Mediterranean range, from Spain to Italy, while $T$. $h$. boettgeri inhabits the coastal areas of the Balkan Peninsula, from Croatia to Greece, including many islands in the Adriadic and Ionian seas, the European part of Turkey, and further inland in the Bosnia and Herzegovina, Serbia, Montenegro, Macedonia, Romania and Bulgaria.

Up to now, some of the Serbian populations of Hermann's tortoise have been included in morphological studies (Ljubisavljević et al., 2012), sexual dimorphism studies (Djordjević et al., 2011), (Djordjević et al., 2013), ecological studies (Golubović et al., 2013) and distributional studies (Ljubisavljević et al., 2014).

The main aim of this paper is to provide basic data about morphological characteristics of the Hermann's tortoise from south-eastern part of Kosovo and Metohija. Our aim was also to test the potential presence of gender differences.

\section{MATERIALS AND METHODS}

Morphological characteristics were analyzed using three localities from south-eastern part of Kosovo and Metohija: village Grnčar $\left(42^{\circ} 19^{\prime} 38^{\prime \prime} \mathrm{N}, 21^{\circ} 24^{\prime} \mathrm{E}\right.$, 507 m a.s.1.), village Melci ( $42^{\circ} 31^{\prime} \mathrm{N}, 21^{\circ} 27^{\prime} \mathrm{E}, 800$ $\mathrm{m}$ a.s.1.) and village Straža $\left(42^{\circ} 31^{\prime} \mathrm{N}, 21^{\circ} 26^{\prime} \mathrm{E}, 716\right.$ $\mathrm{m}$ a.s.1.). We analysed 75 adult Hermann's tortoises (33 males and 42 females). Sex was determined by plastral concavity and by the presence of larger tails in 
males. Specimens smaller than $10 \mathrm{~cm}$ carapace length were considered to be juveniles (Stubbs et al., 1984).

All specimens were measured in the field, photographed and afterwards released at the place of capture.

Morphometric analysis has been done on 7 traits: SCL - midline straight carapace length, from the front of the nuchal scute, to the rear of the carapace; MCW - mid-body carapace width, straight width of the carapace, at the level of the 6th marginals; MaxCW maximal carapace width, width of the carapace at the widest point, usually at the level of the 8th marginals; $\mathrm{CH}$ - carapace height; MPL - midline plastron length; MaxPL - maximal plastron length, length of the plastron from the tips of gulars to the tips of anals; MaxPW - maximal plastron width. All linear measurements were taken with a mechanical calliper (precision 0,01 $\mathrm{mm}$ ) while, midline straight carapace length was taken by a flexible measuring tape (precision $1 \mathrm{~mm}$ ), by the same person (A. S.).

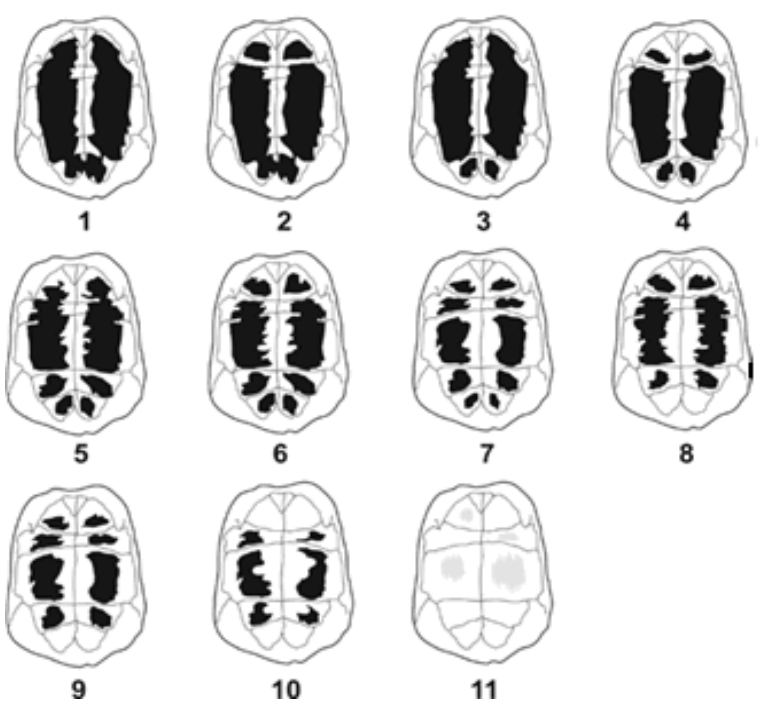

Fig. 1. Range of plastral pigmentation (modified scheme of Guyot \& Devaux, 1997 according to Ljubisavljević et al., 2012): 1) continuous black pigmentation; 2) black spots on humeral scutes are isolated; 3) black spots on anal scutes are isolated; 4) black spots on anal and humeral scutes are isolated; 5) black spots on anal and femoral scutes are isolated; 6) black spots on anal, humeral and femoral scutes are isolated; 7) black spots are isolated on each scute and reduced in size; 8) black spots are lacking on anal scutes, while on humeral and femoral scutes are isolated; 9) black spots are lacking on anal scutes, while on other scutes are isolated and reduced in size; 10) black spots are lacking on anal and humeral scutes, while on other scutes are isolated and reduced in size; 11) black pigmentation is lacking.
We considered the extended plastron black pigmentation (Fig. 1) and frequencies for each pigmentation states were calculated. This was done according to modified scheme of (Guyot \& Devaux, 1997), used in morphological study of the Hermann's tortoise by (Ljubisavljević et al., 2012). Since, preliminary analysis of (Ljubisavljević et al., 2012), revealed no significant sex related variations in the frequencies of black pigmentation, we performed qualitative analysis of these trait on the whole sample.

Programme package STATISTICA (version 7.0) has been used for statistical data analysis. For morphometric characters basic parameters of descriptive statistics have been separately calculated by genders: mean $(\bar{x})$, standard error (SE), range and standard deviation (SD). Analysis of variance (ANOVA) has been used to establish the significance of differences in respect of morphometric characters between the genders.

\section{RESULTS AND DISCUSSION}

\subsection{Morphometric characters}

Descriptive statistics of body size measurements of adult males and females of Hermann's tortoises from south-eastern part of Kosovo and Metohija are presented in Table 1.

The carapace length (SCL) of males ranged from $154.8 \mathrm{~mm}$ to $214.2 \mathrm{~mm}(\bar{x}=180.57 \mathrm{~mm} \pm 2.04)$, respectively, from 164.2 to $232.6 \mathrm{~mm}$ ( $\bar{x}=200.83 \mathrm{~mm}$ \pm 2.17 ) of females (Table 1). The mean value of the maximum carapace width (Max $\mathrm{CW}$ ) of males amounted to $155.17 \mathrm{~mm}( \pm 1.90)$, while that of females was $163.46 \mathrm{~mm}( \pm 1.84)$. The maximum carapace width of $189.6 \mathrm{~mm}$ was recorded in a female individual, while the narrowest carapace of $122.6 \mathrm{~mm}$, measured in one male individual. Maximum measured plastron length (Max PL) in males was $182.3 \mathrm{~mm}$, and in females, $219.6 \mathrm{~mm}$, while the minimum values were measured $137.5 \mathrm{~mm}$ in males and $141.3 \mathrm{~mm}$ in females. Average values of maximum plastron width (Max PW) amounted to $131.73 \mathrm{~mm}( \pm 1.40)$ in males, and $141.13 \mathrm{~mm}( \pm 1.49)$ in females. Carapace height $(\mathrm{CH})$ amounted to an average $91.46 \pm 1.27 \mathrm{~mm}$ in males and $102.78 \pm 1.65 \mathrm{~mm}$, in females.

These obtained values were in accordance with literature data (Willemsen \& Hailey, 1999), (Willemsen \& Hailey, 2003), (Bertolero et al., 2011), (Djordjević et al., 2011), (Ljubisavljević et al., 2012). 
Based on the most important dimensions of carapace and plastron length and width, the Hermann's tortoises from the south-eastern part of Kosovo and Metohija are the most similar to the individuals of the population from the southern part of the Balkan Peninsula (the southern part of Serbia and the northern part of Greece). In relation to the populations from central and eastern Serbia, individuals from our studed area have higher values that is also in accordance with literature data (Djordjević et al., 2011), (Ljubisavljević et al., 2012).

Table 1. Descriptive statistics of morphometric characters of male and female Hermann's tortoise from southeastern part of Kosovo and Metohija. Abbreviations of characters are given in "Materials and Methods".

\begin{tabular}{|l|cccccccc|}
\hline \multirow{2}{*}{ Character } & \multicolumn{4}{|c}{ Male $(\mathrm{n}=33)$} & \multicolumn{5}{c|}{ Female $(\mathrm{n}=42)$} \\
\cline { 2 - 9 } & $\bar{x} \pm \mathrm{SE}$ & $\min$ & $\max$ & $\mathrm{SD}$ & $\bar{x}_{ \pm \mathrm{SE}}$ & $\min$ & $\max$ & SD \\
\hline SCL & $180.57 \pm 2.04$ & 154.8 & 214.2 & 11.75 & $200.83 \pm 2.17$ & 164.2 & 232.6 & 14.09 \\
\hline MCW & $141.22 \pm 1.38$ & 117.3 & 157.3 & 7.94 & $150.86 \pm 1.57$ & 128.2 & 176.2 & 10.22 \\
\hline MaxCW & $155.17 \pm 1.90$ & 122.6 & 174.4 & 10.93 & $163.46 \pm 1.84$ & 137.5 & 189.6 & 11.93 \\
\hline CH & $91.46 \pm 1.27$ & 75.6 & 113.3 & 7.33 & $102.78 \pm 1.65$ & 83.7 & 133.3 & 10.75 \\
\hline MPL & $140.77 \pm 1.78$ & 123.4 & 165.5 & 10.25 & $167.82 \pm 2.39$ & 126.3 & 197.2 & 15.50 \\
\hline MaxPL & $160.27 \pm 1.87$ & 137.5 & 182.3 & 10.76 & $183.75 \pm 2.31$ & 141.3 & 219.6 & 15.01 \\
\hline MaxPW & $131.73 \pm 1.40$ & 109.3 & 147.1 & 8.07 & $141.13 \pm 1.49$ & 120.2 & 163.2 & 9.70 \\
\hline
\end{tabular}

Table 2. ANOVA with sex as the factor. Abbreviations of characters are given in "Materials and Methods". Bold - statistically significant $P$ values $(P<0.05)$.

\begin{tabular}{|l|cc|}
\hline Character & F & $P$ \\
\hline SCL & 44.065 & 0.00000 \\
\hline MCW & 19.881 & 0.00003 \\
\hline MaxCW & 9.595 & 0.00277 \\
\hline CH & 26.763 & 0.00000 \\
\hline MPL & 74.652 & 0.00000 \\
\hline MaxPL & 57.368 & 0.00000 \\
\hline MaxPW & 20.048 & 0.00003 \\
\hline
\end{tabular}

The analysis of variance (ANOVA) showed that sexes significantly differed in all 7 characters (Table 2 ). Females were larger than males for all traits. These results are consistent with published dates for sexual dimorphism of the Testudo genus (Willemsen \& Hailey, 1999), (Willemsen \& Hailey, 2003), (Djordjević et al., 2011), (Ljubisavljević et al., 2012). The observed direction of sexual size dimorphism, with females larger than males is most common in chelonians and is usually explained by fecundity selection (Ceballos et al., 2013).

\subsection{Qualitative traits}

Analysis of plastron black pigmentation level has shown that in individuals of the Hermann's tortoise from the southeastern part of Kosovo and Metohija seven out of 11 states are present. The most common are the conditions that determine the fragmented and reduced black pigmentation (states 7 and 10). They were present in $37.7 \%$ and $29.5 \%$ of individuals. This type of plastron pigmentation is characteristic for the Hermann's tortoises from the southern part of Serbia (Ljubisavljević et al., 2012). On the other hand, conditions that show high level of black pigmentation (states 2 and 4), are present in only $11.4 \%$ of individuals. Pigmentation states 1, 3, 8 and 9 were not identified in the analyzed sample.

\section{CONCLUSION}

In this paper we present the results of the analysis of morphological characteristics of the Hermann's tortoise from south-eastern part of Kosovo and Metohija. Results of descriptive statistics showed that the Hermann's tortoises from the south-eastern part of

\section{Biology}


Kosovo and Metohija are the most similar to the individuals of the populations from the southern part of the Balkan Peninsula (the southern part of Serbia and the northern part of Greece). Variance analysis found the statistically significant difference in body size between the genders. Females had higher values for all characters. Fragmented and reduced plastron black pigmentation prevailed in 2/3 of individuals in the population.

Our results of analysis of external morphology of the Hermann's tortoise from south-eastern part of Kosovo and Metohija, are in accordance with previous studies of this species from Serbia.

\section{REFERENCES}

Berry, J.F., \& Shine, R. 1980. Sexual size dimorphism and sexual selection in turtles (order testudines). Oecologia,44(2), pp. 185-191. doi:10.1007/BF00572678.

Bertolero, A., Cheylan, M., Hailey, A., Livoreil, B., \& Willemsen, R.E. 2011. Testudo hermanni (Gmelin 1789): Hermann's tortoise. In A.G.J. Rhodin, P.C.H Pritchard, P.P. van Dijk, R.A. Saumure, K.A. Buhlmann, J.B. Iverson, \& R.A. Mittermeier Eds., Conservation biology of freshwater turtles and tortoises: A compilation project of the IUCN/SSC tortoise and freshwater turtle specialist group. Chelonian Research Monographs. 5, 059.1-059.20.

Bour, R. 1997. Testudo hermanni. In J.P. Gasc, A. Cabela, J. Crnobrnja-Isailović, D. Dolmen, K. Grossenbacher, P. Haffner, . . . A. Zuiderwijk Eds., Atlas of Amphibians and Reptiles in Europe.Paris: Societas Europaea Herpetologica and Museum National d'Histoire Naturelle, IEGB/SPN., pp. 178-179.

Cheylan, M. 2001. Testudo hermanni Gmelin, 1789: Griechische Landschildkröte. In U. Fritz Ed., Handbuch der Reptilien und Amphibien Europas.Wiebelsheim: Aula-Verlag. d. 3/IIIA, Schildkröten I.

Djordjević, S., Đurakić, M., Golubović, A., Ajtić, R., Tomović, Lj., \& Bonnet, X. 2011. Sexual body size and body shape dimorphism of Testudo hermanni in centarl and eastern Serbia. Amphibia-Reptilia, 32, pp. 445-458.

Djordjević, S., Tomović, Lj., Golubović, A., Simović, A., Sterijovski, M., Đurakić, M., \& Bonnet, X. 2013. Geographic (in-) variability of gender-specific traits in Hermann's tortoise. Herpetological Journal, 23, pp. 67-74.

Fritz, U., Auer, M., Bertolero, A., Cheylan, M., Fattizzo, T., Hundsdorfer, A.K., . . . Wink, M. 2006. A rangewide phylogeography of Hermann's tortoise, Testudo hermanni (Reptilia: Testudines: Testudinidae): Implications for taxonomy. Zoologica Scripta, 35(5), pp. 531-543. doi:10.1111/j.14636409.2006.00242.x

Golubović, A., Bonnet, X., Djordjević, S., Djurakić, M., \& Tomović, Lj. 2013. Variations in righting behaviour across Hermann's tortoise populations. Journal of Zoology, 291(1), pp. 69-75.

Guyot, G., \& Devaux, B. 1997. Variation in shell morphology and color of Hermann's tortoise, Testudo hermanni, in southern Europe. Chelonian Conservation and Biology, 2, pp. 390-395.

Ljubisavljević, K., Džukić, G., Vukov, D.T., \& Kalezić, L.M. 2014. Distribution patternsof Hermann's Tortoise Testudo hermanni Gmelin, 1789, in the region of former Yugoslavia (Testudines: Testudinidae). Herpetozoa, 26(3-4), pp. 125-138.

Ljubisavljević, K., Vukov, T., Džukić, G., \& Kalezić, M. 2012. Morphological variability of the Hermann's tortoise (Testudo hermanni) in the Central Balkans. Acta Herpetologica, 7(2), pp. 253-262.

Stubbs, D., Hailey, A., Pulford, E., \& Tyler, W. 1984. Population ecology of European tortoise: Review of field techniques. Amphibia-Reptilia, 5, pp. 57-68.

Tomović, Lj., Ajtić, R., Ljubisavljević, K., Urošević, A., Jović, D., Krizmanić, I., . . . Džukić, G. 2014. Reptiles in Serbia: Distribution and diversity patterns. Bulletin of the Natural History Museum, 7, pp. 129-158.

Willemsen, R.E., \& Hailey, A. 1999. Variation of adult body size of the tortoise Testudo hermanni in Greece: Proximate and ultimate causes. Journal of Zoology, 248, pp. 379-396.

Willemsen, R.E., \& Hailey, A. 2003. Sexual dimorphism of body size and shell shape in European tortoises. Journal of Zoology, 260, pp. 353-365.

*E-mail: nenad.labus@pr.ac.rs 